\title{
MONITORING KEHADIRAN DAN PERILAKU PESERTA DIDIK DENGAN SISTEM INTEGRASI PRESENSI DAN BUKU PENGHUBUNG BERBASIS ANDROID
}

\author{
Basri $^{1}$, Asnari $^{2},{\text { Rosmawati } \operatorname{Tamin}^{3}, \text { Syarli }^{4}, \text { Nurahmad }^{5}}^{5}$ \\ ${ }^{1}$ Teknik Informatika, Universitas Al Asyariah Mandar, Polewali Mandar, Indonesia \\ ${ }^{2,3,4}$ Sistem Informasi, Universitas Al Asyariah Mandar, Polewali Mandar, Indonesia \\ ${ }^{4}$ Universitas Fajar, Makassar, Indonesia
}

'basri@unasman.ac.id, ${ }^{2}$ asnari@ mail.unasman.ac.id, ${ }^{3}$ rosmawatitamin@ @ail.unasman.ac.id,
${ }^{4}$ syarli@ $@$ mail.unasman.ac.id, ${ }^{4}$ nur.rahmad.0002@ gmail.com

\begin{abstract}
ABSTRAK
Penelitian ini bertujuan membangun sistem monitoring dengan penggabungan fungsi presensi dan buku penghubung berbasis Aplikasi Android. Penelitian ini dilakukan menggunakan sampel data di SDN 066 Pekkabata, Kabupaten Polewali Mandar, Sulwaesi Barat. Aplikasi ini di bangun dengan menggunakan model Client-Server dimana servernya berbasis website dan Clientya berbasis Aplikasi Android. Web server yang dibangun digunakan sebagai tempat pengolahan data seperti data peserta didik, guru, presensi dan buku penghubung. Data yang tersimpan dalam database server selanjutnya dapat di akses oleh aplikasi client yang berbasis sistem operasi Android. Selain itu, client juga dapat melakukan penginputan data presensi. Data yang diinput kemudian tersimpan dalam database server dengan menggunakan Web service JSON (JavaScript Object Notation). Implementasi sistem pada lokasi penelitian menunjukkan bahwa penerapan sistem dapat lebih memudahkan orang tua dalam memantau kehadiran dan perilaku anaknya di sekolah, selain itu bagi guru dan wali kelas, pengembangan sistem ini memudahkan dalam pengelolaan presensi dan buku penghubung, serta sistem yang dikembangkan dapat memfasilitasi kepala sekolah memonitor kehadiran peserta didik dan perilakunya sehingga dapat menjadi bahan evaluasi pendidikan.
\end{abstract}

Kata Kunci- Buku Penghubung, Presensi, Android, Client-Server.

\begin{abstract}
This study aims to build a monitoring system by combining attendance functions and a contact book based on Android applications. This research was conducted by data samples at SDN 066 Pekkabata, Polewali Mandar Regency, West Sulawesi. This system was built using the Client-Server model, where the server was based on the website, and the Client was based on the Android Application. The webserver was used as a platform for processing data such as student, teacher, attendance, and connecting book. Data stored in a database server and can be accessed by a client application based on the Android operating system. Also, the client can also input the presence data. The inputted data then stored in the database server by using the JSON (JavaScript Object Notation) Web service. Implementation of the system at the research location showed that the application of the system could make it easier for parents to monitor their child's attendance and behavior at school, in addition to teachers, also the development of this system makes it easier to manage attendance and connecting books, as well as the developed system can facilitate the headmaster of the school monitors the student's attendance and behavior and becomes an educational evaluation material.
\end{abstract}

Keywords-Connecting Book, Presence, Android, Client-Server. 


\section{PENDAHULUAN}

Usaha dalam mendidik kedisiplinan peserta didik bukan hanya saja tanggung jawab pihak sekolah saja, tetapi orang tua juga harus ikut berperan serta [1]. Penerapan aturan kedisiplinan di sekolah ataupun di rumah merupakan hal yang sangat penting dalam tumbuh kembang anak [2]. Selain dengan pendekatan pendidikan pembelajaran kelas, dan konseling peserta didik, salah satu cara mengawasi prosesnya adalah dengan memanfaatkan presensi dan buku penghubung di sekolah, agar kehadiran dan perilaku peserta didik dapat terkontrol dengan baik [3]. Penggunaan buku penghubung ini tentunya sangat bermafaat sebagai sarana komunikasi antara pendidik di sekolah dengan orang tua peserta didik. Hanya saja dengan model manual yang saat ini banyak diimplementasikan, Informasi terkait kondisi peserta didik kadang tidak secara realtime dan mudah terpantau setiap saat. Saat ini banyak peserta didik yang justru kurang dipantau oleh orang tuanya akibat kurangnya perhatian terhadap buku penghubung ini, sehingga hal ini dapat mengakibatkan tingkat kedisplinan peserta didik terus menurun dan perilakunya terhadap guru dan temantemanya di sekolah semakin kurang baik. Untuk itulah dengan kemajuan teknologi jaringan dan integrasi sistem client-server yang banyak dikembangkan saat ini, sangat memungkinkan bahwa buku penghubung yang awalnya berupa buku cetak dapat ditransformasi ke bentuk digital dengan Aplikasi berbasis Client-Server dengan memanfaatkan web Service dan aplikasi android, sehingga kegitan monitoring yang melibatkan guru, wali kelas, kepala sekolah dan orang tua peserta didik dapat terus terpantau setiap saat.

Integrasi sistem kehadiran/presensi dengan aplikasi monitoring peserta didik pernah dilakukan dengan sistem buku penghubung berbasis Website. Aplikasi buku penghubung berbasis web yang dibangun digunakan sebagai media komunikasi antara orangtua murid dan pihak sekolah secara online [4]. Kelemahannya adalah karena dibangun hanya dengan sistem berbasis website sehingga hakikat monitoring dengan realtime kadang tidak dapat terpantau, terkecuali orang tua peserta didik mengakses website yang disediakan. Penelitian lainnya juga sistem monitoring kehadiran peserta didik di sekolah dengan menggunakan Finger Print dan Short Masseges Service (SMS) Geteway, hal yang dideteksi pada sistem ini yaitu jam dan tanggal peserta didik tersebut hadir, sehingga akan tercatat kapan peserta didik tersebut hadir, kapan peserta didik tersebut pulang dan sebagainya. Sementara untuk monitoring kehadiran melalui SMS diperlukan sistem yang menggunakan SMS gateway [5]. Selain itu ada pula Aplikasi Monitoring Absensi yang menggunakan Aplikasi berbasis mobile dengan teknologi Near Field Communication (NFC), dimana data absensi juga disajikan berdasarkan interval waktu yang diinginkan seperti data pada satuan hari, minggu, bulan dan tahun yang akan disajikan pada aplikasi web yang telah di syncronize dengan server [6].
Beberapa pendekatan Aplikasi dengan penggunaan alat absensi sidik jari dirasa tidak praktis dan ekonomis, karena selain karena harganya yang cukup mahal, penggunaannya juga memerlukan pendataan database sidik jari seluruh peserta didik, sehingga kurang praktis dalam penerapannya [7]. Sedangkan penggunaan teknologi NFC memerlukan dua perangkat untuk berkomunikasi, yang dinamakan NFC Reader dan NFC Tags. Penggunaan perangkat ini untuk proses presensi kurang praktis karena memerlukan dua perangkat yang dapat beroperasi, sementara untuk monitoring mengunakan teknologi SMS Geteway sehingga orang tua harus berulangkali mengirimkan ke wali kelas untuk mendaptkan informasi kehadiran anaknya di sekolah, informasi yang di dapat juga terbatas oleh panjang karakter SMS [8].

Dari analisa tersebut, maka pengembangan Aplikasi berbasis Client-Server dengan interface Aplikasi Android akan dapat menjawab kelemahan-kelemahan dari riset sebelumnya. Pengembangan Aplikasi Back-End untuk administrator dikerjakan dengan sistem berbasis Website sedangkan di sisi client dibuat dengan interface Aplikasi Android. Hasil observasi pada guru di lokasi penelitian juga menunjukkan bahwa semua guru yang memiliki smartphone android, setuju akan penggunaan android dalam pengisian presensi dan Buku Penghubung peserta didik karena dianggap sangat efisien. Untuk itulah pada penelitian ini dikembangkan sebuah aplikasi yang mengintegrasikan presensi dengan buku penghubung menjadi suatu aplikasi $e$-monitoring peserta didik, sehingga sistem ini diharapkan dapat memberikan cara baru dalam melakukan monitoring kehadiran dan perilaku peserta didik di sekolah.

\section{TINJAUAN PUSTAKA}

\subsection{Presensi}

Presensi adalah pencatatan dan pengolahan data kehadiran yang dilakukan secara terus menerus [9]. Presensi atau kegiatan absensi merupakan sebuah kegiatan pengambilan data untuk mengetahui jumlah kehadiran pada suatu acara. Setiap kegiatan yang membutuhkan informasi mengenai peserta tentu akan melalui proses absensi. Hal ini juga terjadi pada proses kegiatan belajar mengajar di sekolah. Kegunaan absensi ini selain sebagai alat evaluasi kegiatan pembelajaran juga menjadi alat kontrol dan media pendisiplinan peserta didik. Penggunaan dalam arti yang luas absen merupakan ketidakhadiran pegawai di tempat kerjanya pada saat pegawai harus bekerja, sehingga penggunaannya meluas pada semua aspek kegiatan termasuk untuk pelajar atau peserta didik di sebuah sekolah [10].

\subsection{Monitoring}

Monitoring atau pemantauan adalah kegiatan yang dilakukan untuk mengecek penampilan dan aktivitas yang sedang dilaksanakan, kegiatan pengumpulan data yang 
relavan secara sistematis dan berkelanjutan yang berkaitan dengan proses tertentu tanpa mengadakan pertimbangan terhadapnya [11]. Monitoring (pemantauan) kegiatan peserta didik berbasis sistem berfungsi sebagai alat kontrol kegiatan belajar mengajar yang terintegrasi dan akurat sehingga dapat memudahkan guru, wali kelas, dan wali murid serta kepala sekolah [12]. Pemantauan tentunya harus dilakukan secara berkelanjutan sejalan dengan kegiatan pembelajaran dan aktifitas akademik lainnya sehari hari.

\subsection{Buku Penghubung}

Buku penghubung merupakan media komunikasi secara tidak langsung yang didalamnya menerangkan perihal pertumbuhan dan perkembangan peserta didik selama berada di dalam proses pembelajaran untuk dilaporkan kepada orang tua peserta didik [13]. Ketika peserta didik telah masuk sekolah tidak berarti tanggung jawab sepenuhnya berpindah kepada guru, dan kepala sekolah. Peranan orang tua juga sangat penting untuk perkembangan anaknya, sehingga atas dasar hal tersebut dibuatlah sebuah buku penghubung sebagai media komunikasi antara guru dan orang tua. Buku penghubung ini bagi orang tua merupakan alat informasi untuk mengetahui kegiatan anaknya disekolah seperti mengetahui informasi perkembangan anaknya di sekolah [4]. Buku Penghubung juga menjadi salah satu syarat kelengkapan Admistrasi Sekolah, bagi yang sudah menerapkan kurikulum 2013 [14].

\subsection{Client-Server}

Client - Server adalah sebuah model komunikasi 2 komputer atau lebih yang berfungsi melakukan pembagian tugas [15]. Client bertugas untuk melakukan input, update, penghapusan, dan menampilkan data sebuah database. Sementara server bertugas menyediakan pelayanan untuk melakukan manajemen, yaitu menyimpan dan mengolah database.

\section{METODE YANG DIUSULKAN}

Sistem dibangun dengan konsep client server, dimana dari sisi client diakses dengan interface Aplikasi berbasis Mobile Android sebagai Fornt-End, sedangkan dari sisi server sebagai Back-End, dibangun dengan Aplikasi berbasis website. Penelitian ini di lakukan di SDN 066 Polewali Mandar sebagai sampel pengujian lapangan. Data yang di butuhkan dalam penelitian berupa Data Presensi, Data Buku Penghubung, Data Siswa, Data Guru, Data Kelas dan Data Mata Pelajaran.

\subsection{Kerangka Sistem}

Kerangka sistem berikut memuat input, proses dan output, sebagaimana ditunjukkan pada gambar 1. Admin sekolah melakukan input data sekolah, seperti data guru, data siswa, dan kelola akun user sedangkan wali kelas melakukan rekap absensi mencetak dan mengisi buku penghubung yang kemudian akan di simpan ke dalam database Mysql aplikasi server Berbasis Web.

Guru Melakukan Penginputan data Presensi melalui aplikasi android yang datanya akan diproses oleh script PHP yang kemudian di simpan dalam database server.

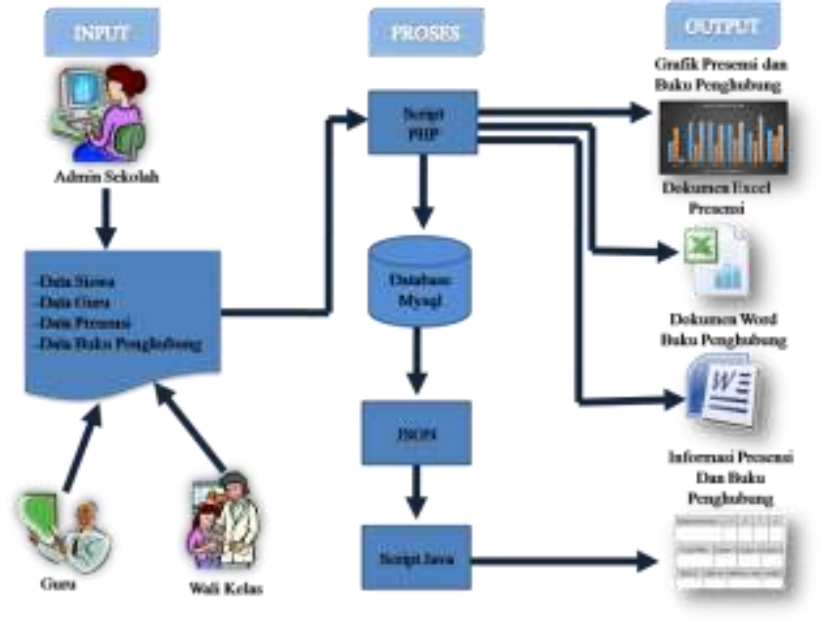

Gambar 1. Kerangka Sistem

Untuk menampilkan output Grafik Presensi dan buku penghubung, dokumen exel presensi, dokumen word buku penghubung semua di proses oleh script PHP dengan mengambil data dari database server sedangkan untuk menampilkan informasi kehadiran dan catatan perilaku siswa di aplikasi Android mengambil data dari database server dengan script java dan kemudian diterjemahkan oleh JSON.

Alur kerja sistem Back-End (admin) sebagaimana ditunjukkan pada Flowchart Gambar 2, dimana aplikasi integrasi presensi dan buku penghubung berbasis android dimonitoring dari sisi admin sehingga kehadiran dan perilaku siswa dapat tergambarkan. Sementara alur kerja sistem Front-End (user) dalam flowchart pada Gambar 3 menunjukkan aplikasi user android dari sisi user sebagai orang tua siswa.

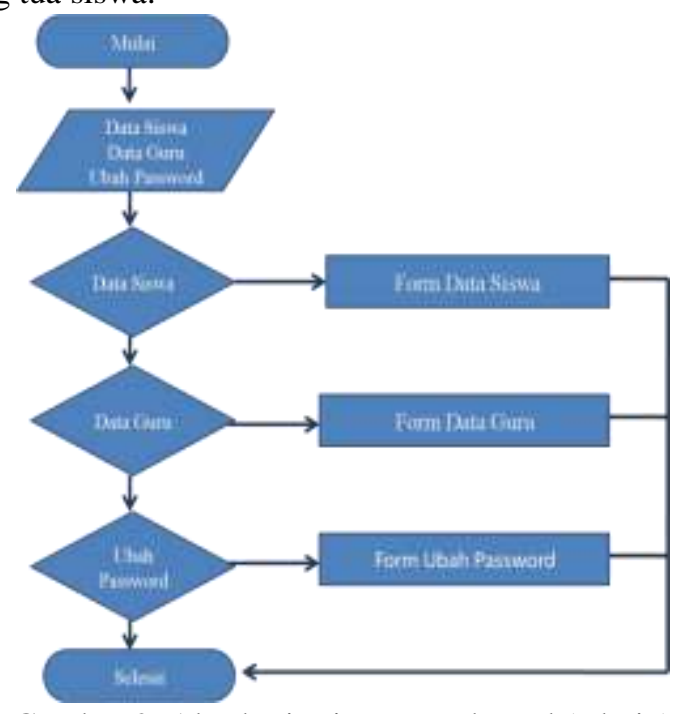

Gambar 2. Alur kerja sistem Back-End (admin) 
Jurnal Ilmiah Ilmu Komputer Vol. 5, No. 1, April 2019

Fakultas Ilmu Komputer

Universitas AL Asyariah Mandar

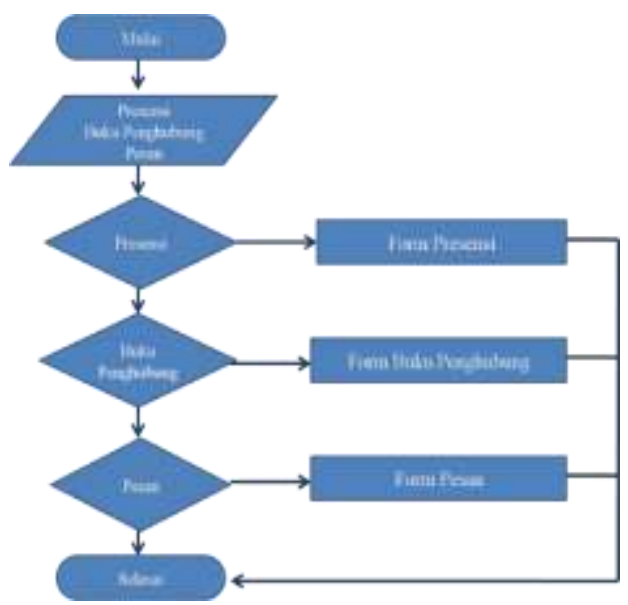

Gambar 3. Alur kerja sistem Front-End (user)

\section{HASIL PENELITIAN}

Penelitian ini menghasilkan sebuah Aplikasi emonitoring siswa berbasis android yang dapat digunakan oleh orang tua siswa untuk monitoring kehadiran dan perilaku anaknya di sekolah. Bukan hanya itu aplikasi ini juga sudah terintegrasi dengan aplikasi presensi sehingga dapat memudahkan guru dalam melakukan pengisian absensi hanya dengan menggunakan smartphone Android. Aplikasi ini dibangun menggunakan prinsip client-server dimana servernya berbasis web dan clientnya berbasis android.

Aplikasi emonitoring ini terdiri dari 5 pengguna yaitu pertama Admin yang melakkan pengolahan data seperti data siswa, guru dan data akun user. Kedua, Wali Kelas dapat mengelola absensi dan melakukan penginputan catatan perilaku siswa (Buku penghubung). Ketiga, Kepala Sekolah dapat memantau jalanya keseluruhan aktifitas dalam sistem namun tidak dapat melakukan proses input maupu edit data. Keempat adalah guru yang dapat melakukan pengisian presensi dengan menggunakan smartphone android sedangkan yang kelima adalah orang tua siswa yang dapat melakukan monitoring kehadiran dan mengisi catatan perilaku siswa.

\subsection{Hasil Pengembangan Interface Aplikasi}

Setelah mengumpulkan, menganalisis, dan merancang maka penulis mengimplementasikan semuanya untuk terciptanya aplikasi Integrasi presensi dan buku penghubung berbasis android untuk monitoring kehadiran dan perilaku siswa.

\subsubsection{Implementasi Desain web admin (Back-End)}

Implementasi Desain web admin ini diperuntukan untuk admin dalam mengelola data seperti data siswa, guru dan mengelola akun user.

\section{a. Halaman Login admin}

Halaman login admin yaitu halaman yang tampil pertama kali serta admin harus mengisikan username dan password. Ketika admin salah menginputkan username dan password maka tidak masuk ke halaman selanjutnya. Halaman login admin dapat dilihat pada Gambar 4.
(P) ISSN 2442-451X

(O) ISSN 2503-3832

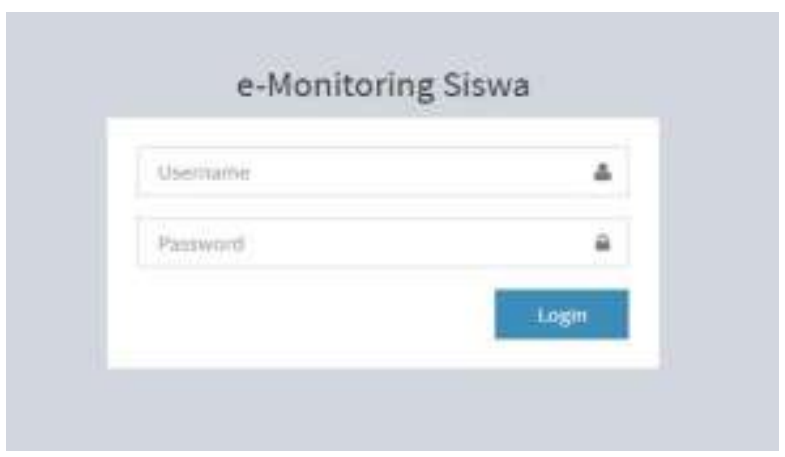

Gambar 4. Halmana Login Admin

\section{b. Halaman Home Admin}

Halaman home Admin ini muncul ketika admin berhasil login di website. Berikut adalah rancangan halaman home admin dapat dilihat pada Gambar 5 berikut.

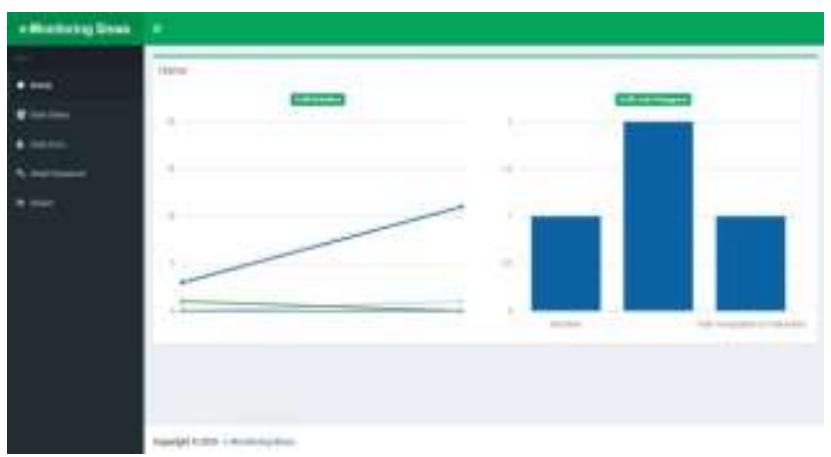

Gambar 5. Halaman Home Admin

\section{c. Halaman data siswa}

Halaman data siswa adalah halaman yang menampilkan form kelola data siswa, pada halaman ini admin dapat menambahkan, mengedit dan menghapus data siswa. Halaman ini muncul ketika admin memilih button data siswa. Berikut adalah halaman data siswa dapat dilihat pada Gambar 6.

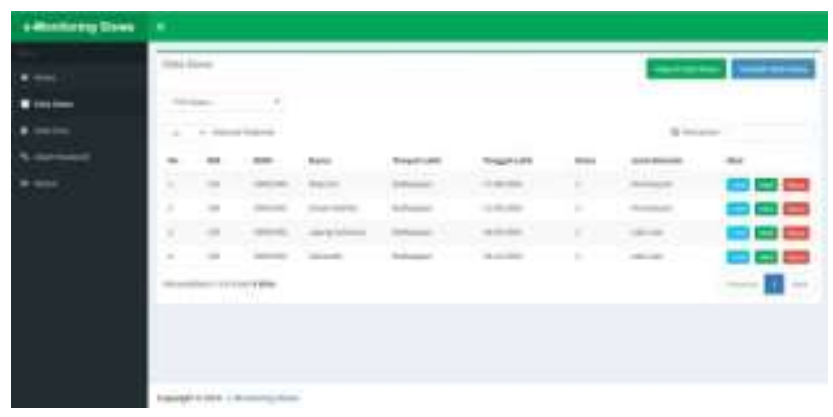

Gambar 6. Halaman data siswa

\section{d. Halaman data guru}

Halaman data guru adalah halaman yang menampilkan form kelola data guru, pada halaman ini admin dapat menambahkan, mengedit dan menghapus data guru. Halaman ini muncul ketika admin mengklik button data guru. Berikut adalah halaman data guru dapat dilihat pada Gambar 7. 
Jurnal Ilmiah Ilmu Komputer Vol. 5, No. 1, April 2019

Fakultas Ilmu Komputer

Universitas AL Asyariah Mandar

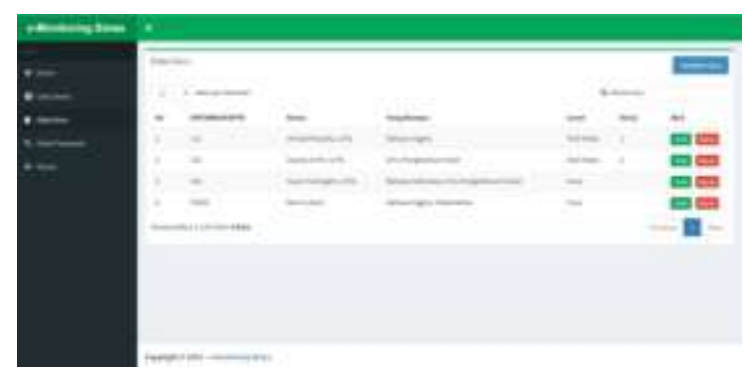

Gambar 7. Halaman data Guru

\subsubsection{Implementasi desain user android (Front-End)}

Implementasi Desain user ini diperuntukan untuk orang tua siswa dalam memonitoring kehadiran dan perilaku anaknya disekolah juga untuk guru dalam melakukan pengisisan presensi siswa menggunakan smartphone android.

\section{a. Halaman Login User (Android)}

Halaman Login user (androd) adalah halaman yang tampil pertamakali dalam hal ini orang tua siswa ataupun guru harus memasukkan username dan password yang di dapatkan dari admin sekolah. Jika username dan password yang dimasukkan salah maka tidak masuk ke halaman selanjutnya. Halaman login user dapat dilihat pada gambar 8.

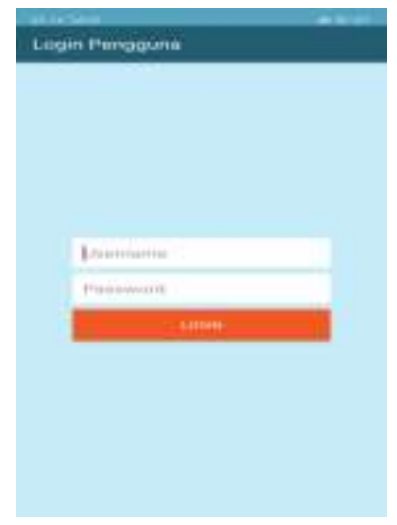

Gambar 8. Halaman Login user (android)

\section{b. Halaman Home user (orang tua siswa)}

Halaman Home user adalah halaman yang muncul setelah user berhasil melakukan login. Halaman ini menampilkan form monitoring siswa. Berikut adalah halaman Home user dapat dilihat pada Gambar 9.

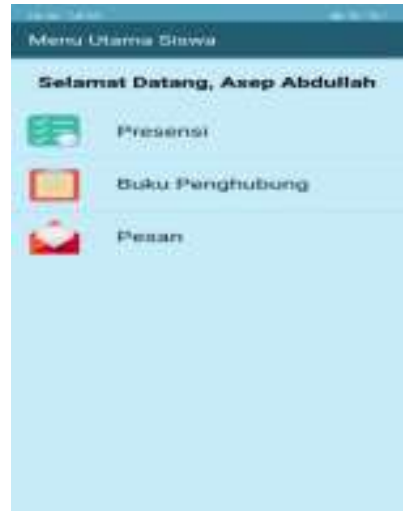

Gambar 9. Halaman Home user (orang tua siswa)

c. Halaman Presensi

Halaman presensi adalah halaman yang muncul ketika user mengkiik button presensi yang digunakan untuk memonitoring kehadiran di sekolah, cukup dengan memilih bulan dan mata pelajaran, maka akan menampilkan informasi monitoring. Berikut adalah halaman presensi dapat dilihat pada Gambar 10.

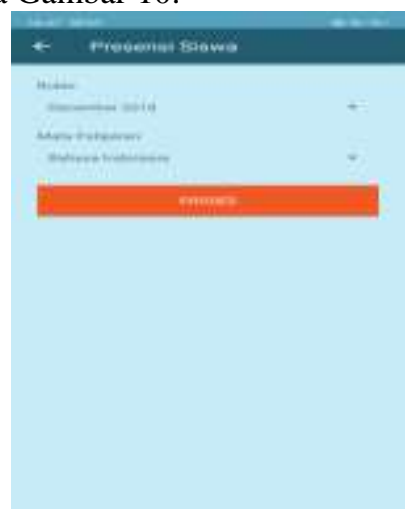

Gambar 10. Halaman Presensi

\section{d. Halaman Buku Penghubung}

Halaman buku penghubung halaman yang muncul ketika user mengklik button Buku Penghubung. Halaman ini digunakan untuk memonitoring perilaku siswa di sekolah. Berikut adalah halaman buku penghubung dapat dilihat pada Gambar 11.

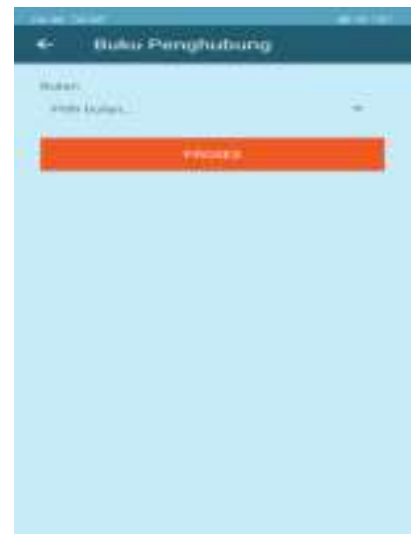

Gambar 11. Halaman Pesan 
Jurnal Ilmiah Ilmu Komputer Vol. 5, No. 1, April 2019

Fakultas Ilmu Komputer

Universitas AL Asyariah Mandar

\section{e. Halaman Pesan}

Halaman ini menampilkan pesan/atau informasi yang dikirim oleh wali kelas melalui aplikasi web. Berikut adalah halaman data anggota teknisi dapat dilihat pada Gambar 12.

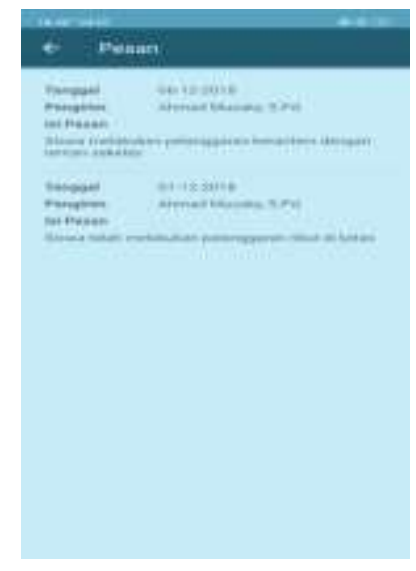

Gambar 12. Halaman Pesan

\subsection{Pengujian Aplikasi}

Aplikasi Integrasi Aplikasi Presensi dan buku penghubung berbasis web dan Android untuk monitoring kehadiran dan perilaku siswa diuji dengan model pengujian Whitebox, Balckbox dan pengujian lapangan.

Whitebox Testing merupakan cara pengujian dengan melihat ke dalam modul untuk meneliti kode-kode program yang ada, dan menganalisis apakah ada kesalahan atau tidak. Jika ada modul yang menghasilkan output yang tidak sesuai dengan proses bisnis yang dilakukan, maka barisbaris program, variabel, dan parameter yang terlibat pada unit tersebut dicek satu persatu dan diperbaiki, kemudian dicompile ulang. Tabel hasil pengujian yang telah dilakukan sebagaimana ditunjukkan pada Tabel 1.

Tabel 1. Hasil pengujian Whitebox

\begin{tabular}{ccccc}
\hline No & Flowgraph & $\begin{array}{c}\text { Independe } \\
\text { nt } \\
\text { Path }\end{array}$ & Region & $\begin{array}{c}\text { Kompleksitas } \\
\text { siklomatis }\end{array}$ \\
\hline 1 & Menu Admin & 4 & 4 & 4 \\
2 & $\begin{array}{c}\text { Menu home } \\
\text { user pada } \\
\text { android }\end{array}$ & 4 & 4 & 4 \\
& Jumlah & $\mathbf{8}$ & $\mathbf{8}$ & $\mathbf{8}$ \\
\hline
\end{tabular}

Berdasarkan tabel hasil pengujian whitebox diatas maka disimpulkan bahwa program aplikasi yang dirancang dianggap valid dan bebas dari kesalahan logika.

Blackbox testing adalah pengujian yang dilakukan hanya mengamati hasil eksekusi melalui data uji dan memeriksa fungsional dari perangkat lunak. Dari hasil pengujian yang dilakukan semua Form pada aplikasi web dan android beserta Action Button yang ada pada form semua berfungsi dengan baik sesuai dengan fungsinya masing-masing.

Dari hasil pengujian yang telah dilakukan di SDN 066 Pekkabata, Aplikasi emonitoring siswa ini berjalan sesuai dengan yang diharapkan, mulai dari Admin, Kepala Sekolah, Wali Kelas, Guru dan Orang Tua Siswa dapat mengfungsikan aplikasi ini sesuai dengan fungsinya masing-masing.

\section{KESIMPULAN}

Berdasarkan hasil penelitian yang telah dilakukan mulai dari awal hingga proses penngembangan, pengujian, dan evaluasi lapangan, maka dengan adanya integrasi Aplikasi presensi dan buku penghubung ini dapat memberikan kemudahan bagi orang tua dalam memantau kehadiran dan perilaku anak-anaknya di sekolah. Bagi guru dan wali kelas sangat memudahkan dalam mengelola presensi dan buku penghubung, sedangkan bagi Kepala Sekolah, Aplikasi ini sangat memudahkan dalam mamantau Kehadiran dan perilaku peserta didik secara umum, sekaligus bisa menjadi bahan evaluasi jika ada permasalahan yang berkaitan dengan kehadiran dan perilaku siswa.

Pengembangan lebih lanjut terkait sistem yang telah dibangun adalah umpan balik tindakan yang belum disertakan dalam Aplikasi berbasis Android yang ada di sisi User. Umpan Balik tersebut berupa fitur balas pesan kepada guru dan wali kelas berdasarkan laporan yang masuk.

\section{UCAPAN TERIMA KASIH}

Terima kasih diucapkan kepada seluruh tim kerja penelitian yang terlibat. Juga ucapan terima kasih kepada Kepala SDN 066 Pekkabata beserta jajarannya atas support data dan partisipasi dalam pengembangan dan pengujian Aplikasi.

\section{Daftar Pustaka}

[1] M. Umar, "Peranan orang tua dalam peningkatan prestasi belajar anak," J. EDUKASI J. Bimbing. Konseling, vol. 1, no. 1, pp. 20-28, 2015.

[2] H. Permono, "Peran orangtua dalam optimalisasi tumbuh kembang anak untuk membangun karakter anak usia dini," 2013.

[3] I. Rahmawati, H. U. Kaltsum, and S. S. M. Hum, "Manfaat Penggunaan Buku Penghubungsebagai Media Komunikasi Guru Dengan Orang Tuasiswa Kelas IIA SD Muhammadiyah 3 Nusukan Surakarta.” Universitas Muhammadiyah Surakarta, 2017.

[4] H. Firmansyah, S. Suryatiningsih, and B. Siswanto, "Aplikasi Buku Penghubung Sd Ar-rafi Berbasis Web,” eProceedings Appl. Sci., vol. 3, no. 1, 2017.

[5] D. A. Diartono, "Integrasi Sistem Presensi Finger Print dan Sistem Sms Gateway untuk Monitoring Kehadiran Siswa," Dinamik, vol. 15, no. 1, 2010.

[6] I. Neforawati, M. I. Fareza, and V. Juniarti, 
Universitas AL Asyariah Mandar

"Rancang Bangun Aplikasi Sistem Informasi Monitoring Absensi Mahasiswa Politeknik Negeri Jakarta Menggunakan Teknologi NFC Pada Android," J. Poli-Teknologi, vol. 14, no. 2, 2015.

[7] I. MADE and D. SUSILA, "SISTEM ABSENSI MAHASISWA MENGGUNAKAN METODE BARCODE BERBASIS ANDROID." UPN" veteran" Jawa Timur, 2013.

[8] D. Puspitasari, H. Hendry, and R. Somya, "Student Monitoring System pada J2ME menggunakan Web Service (Studi Kasus: SMK Telekomunikasi Tunas Harapan Tengaran)," d'CARTESIAN, vol. 2, no. 1, pp. 33-46, 2013.

[9] R. Mulyana and M. Ridwan, “Aplikasi Penggajian Karyawan Berbasis Client-Server Pada PT. Radio Nasional Buana Suara," J. Ilm. Ilmu Ekon. (Jurnal Akuntansi, Pajak dan Manajemen), vol. 5, no. 10, pp. 127-133, 2017.

[10] A. F. Andini, M. Irzal, and R. Arafiyah, "Perancangan dan Implementasi Sistem Absensi Online Berbasis Android di Lingkungan Universitas Negeri Jakarta," 2017.

[11] S. Susanti, "Prototype Sistem Monitoring Siswa Menggunakan Teknologi RFID (Radio Frequency Identification) dan Sms Gateway Berbasis Client Server (Studi Kasus: SMA Santo Paulus Pontianak)," JUSTIN (Jurnal Sist. dan Teknol. Informasi), vol. 2, no. 1, pp. 25-30, 2014.

[12] E. Sutinah, G. N. Azima, and E. F. Imaduddin, "Sistem Informasi Monitoring Akademik Dan Prestasi Siswa Dengan Metode Waterfall," JIEET (Journal Inf. Eng. Educ. Technol., vol. 2, no. 1, pp. 47-59, 2018.

[13] N. R. Khasanah, "IMPLEMENTASI PENGGUNAAN BUKU PENGHUBUNG SEBAGAI SARANA KOMUNIKASI GURU DAN ORANG TUA DI TAMAN KANAKKANAK MASJID KAMPUS UGM," Hanata Widya, vol. 6, no. 5, pp. 69-77, 2017.

[14] A. AR, "Pelaksanaan Manajemen Pembelajaran Berkarakter Dalam Penerapan Kurikulum 2013 Di Kelas Awal Sekolah Dasar," in Prosiding Seminar Pendidikan Nasional, 2013, pp. 1437-1449.

[15] B. Basri, M. Assidiq, and U. Anatasya, "LINEAR CONGRUENT METHOD (LCM) IN TESTING SYSTEM USING CLIENT-SERVER MODEL," IJISCS (International J. Inf. Syst. Comput. Sci., vol. 2, no. 1, pp. 51-58, 2018. 